\title{
ANALISIS MUTU KIMIA DAN ORGANOLEPTIK PUPUK ORGANIK TANDAN KOSONG KELAPA SAWIT DENGAN DOSIS EM-4 BERBEDA
}

\author{
(Analysis of Chemical and Organoleptic Qualities of Organic Fertilizer of Oil Palm Empty Bunch With \\ Different EM-4 Doses)
}

\author{
ADE MAYA MUSTIKA, PENTI SURYANI, TAHRIR AULAWI \\ Prodi Agroteknologi Fakultas Pertanian dan Peternakan \\ Universitas Islam Negeri Sultan Syarif Kasim Riau \\ Email: mayakeren72@yahoo.co.id HP : 082387582975
}

\begin{abstract}
This research was conducted from August to December 2016 at the PEM Laboratory of the Faculty of Agriculture and Animal Sciences State Islamic University of Sultan Syarif Kasim Riau and Central Plantation Service Laboratory. The study aims to 1). Analyzing the chemical and organoleptic qualites of Oil Palm Empty Bunches organic fertilizer with the addition of different EM-4 doses 2). Determine the best quality on the quality of Oil Palm Empty Bunches organic fertilizer. The experimental design was Completely Randomized Design (CRD) and three replications. The treatment were application of (EM4) consist of $0 \mathrm{ml}, 5 \mathrm{ml}, 10 \mathrm{ml}, 15 \mathrm{ml}, 20 \mathrm{ml}$, and $25 \mathrm{ml}$. Results analysis using ANOVA variance, simple linear regression and validity and reliability analysis. The results showed that the addition of EM-4 resulted in quality in accordance with SNI 19-7030-2004 with the dose of $5 \mathrm{ml}, 10 \mathrm{ml}$, and $15 \mathrm{ml}$, respectively, but on the measurement of fertilizer $\mathrm{pH}$ organic Oil Palm Empty Bunches does not meet SNI: 19-7030-2004.
\end{abstract}

Keywords : quality; organic fertilizer; dose EM-4; palm oil

\section{PENDAHULUAN}

Tandan Kosong Kelapa Sawit (TKKS) merupakan limbah padat terbanyak yaitu sekitar 20\% dari jumlah Tandan Buah Segar (TBS) kelapa sawit yang diolah. Pemanfaatan TKKS saat ini adalah langsung disebarkan di kebun sebagai mulsa atau dibuat kompos terlebih dahulu (Nuryanto et al., 2013). TKKS merupakan limbah lignoselulosa dari pabrik kelapa sawit (Rivani et al., 2013) dan materi organik dalam tumpukan besar, akan terjadi proses dekomposisi secara anaerobik atau proses pembusukan skala besar, proses pembusukan tersebut menyebabkan terproduksinya gas-gas yang mencemari atmosfer seperti gas $\mathrm{CH}_{4} \cdot \mathrm{H}_{2} \mathrm{~S}, \mathrm{NH}_{3}$, dan $\mathrm{NO}_{x}$ (Wahyono et al., 2008), yang dapat menimbulkan hama, efek rumahkaca dan pemanasan global.

TKKS memiliki potensi yang cukup besar untuk dapat dimanfaatkan, diantaranya memanfaatkan limbah TKKS sebagai alternatif pembuatan pupuk organik kompos. Puspa (2014) mengatakan, pupuk organik adalah nama kolektif semua jenis bahan organik asal tanaman dan hewan yang dapat dirombak menjadi unsur hara tersedia bagi tanaman. Kompos adalah hasil pembusukan sisa tanaman oleh aktivitas mikroorganisme pengurai (Jannah et al., 2014). Pengembalian bahan organik kelapa sawit ke tanah akan menjaga kelestarian kandungan bahan organik lahan secara langsung dan tidak langsung (Surilawati, 2013). Upaya yang dilakukan untuk mempercepat lama pemeraman pengomposan dilakukan dengan aplikasi mikroorganisme (dekomposer) terpilih dan aktivator.

Aktivator adalah bahan yang dapat mengaktifkan proses pelapukan atau pengomposan (Harahap et al., 2015) seperti penambahan Effective microorganisms 4 (EM4) yang merupakan campuran berbagai mikroorganisme bermanfaat, sehingga dijadikan sebagai aktivator (Suherman et al., 2014) yang dapat bekerja secara efektif dalam mempercepat proses fermentasi bahan organik (Yuniwati et al., 2012). Menurut Toiby dkk. (2015), pemberian EM-4 sebanyak $20 \mathrm{ml}$ dapat meningkatkan sifat kimia kompos TKKS. Bahan organik seperti TKKS dalam proses pengomposan menggunakan bahan EM-4 yang dikombinasikan akan mempercepat perkembangan populasi mikroorganisme di dalam bahan organik tersebut dan dapat meningkatkan mutu kompos. 
Ciri-ciri kompos yang baik adalah berwarna cokelat, berstruktur remah, berkonsistensi gembur dan berbau daun lapuk (Yuliarti, 2009). Produk kompos yang dihasilkan bermutu baik, bebas dari mikroba kontaminan (patogen), memenuhi persyaratan kompos matang dan secara umum sesuai dengan parameter yang dipersyaratkan oleh Permentan Pupuk Organik atau SNI Kompos 2004 (Sahwan et al., 2011).

Peraturan menteri pertanian Republik Indonesia Nomor 28/permentan/ SR.130/ 5/ 2009 Tahun 2009 pasal 1 ayat 10 uji mutu pupuk organik adalah analisis kandungan hara, mineral logam berat dan mikroba patogen yang dilakukan di laboratorium berdasarkan metode analisis yang ditetapkan (Anonim, 2017).

\section{BAHAN DAN METODE}

Penelitian dilaksanakan pada Bulan Agustus sampai dengan Desember 2016. Tempat pelaksanaan di Kandang Tertutup Ternak Ayam Potong dan Laboratorium PEM Fakultas Pertanian dan Peternakan UIN Suska Riau, serta Laboratorium Central Plantation Services JI.HR Soebrantas No.134 Panam, Bahan yang digunakan adalah TKKS, EM-4, pupuk kandang (feses kerbau), gula merah, dan aquades. Alat yang digunakan adalah parang, ember, gelas ukur, timbangan, terpal, plastik pembungkus, alat tulis, dan kamera.

Analisis mutu pupuk organik TKKS menggunakan metode Rancangan Acak Lengkap (RAL) dengan 6 perlakuan dan 3 ulangan. Komposisi perlakuan mutu pupuk organik yaitu: TKKS $5 \mathrm{~kg}$, EM-4 $25 \mathrm{ml} / \mathrm{L}$, feses Kerbau 1,5 kg (Marlina et al., 2013 dan Fatokah, 2012), dengan 6 taraf perlakuan: $5 \mathrm{~kg}$ TKKS (M0), $5 \mathrm{~kg}$ TKKS + $5 \mathrm{ml} \mathrm{EM-4} \mathrm{(M1),} 5 \mathrm{~kg}$ TKKS + $10 \mathrm{ml} \mathrm{EM-4} \mathrm{(M2),} 5 \mathrm{~kg}$ TKKS $+15 \mathrm{ml}$ EM-4 (M3), $5 \mathrm{~kg}$ TKKS + $20 \mathrm{ml}$ EM-4 (M4) (Toiby et al., 2015), $5 \mathrm{~kg}$ TKKS + $25 \mathrm{ml}$ EM-4 (M5), yang diulang sebanyak 3 ulangan.

\section{HASIL DAN PEMBAHASAN}

Dari Tabel 1. dapat dilihat bahwa hasil untuk sifat kimia pupuk organik yang terbaik terdapat pada sampel M1 yang diberi $5 \mathrm{~kg}$ TKKS + $1.5 \mathrm{~kg}$ feses kerbau + $5 \mathrm{ml} \mathrm{EM-4}$ untuk parameter $\mathrm{N}$-total dan $\mathrm{P}$-total namun rendah pada parameter K-total dan C-Organik. Sedangkan untuk parameter K-total dan C-Organik terbaik terdapat pada sampel M2 yang diberi $5 \mathrm{~kg}$ TKKS $+1.5 \mathrm{~kg}$ feses kerbau + $10 \mathrm{ml}$ EM-4 untuk unsur K-total dan sampel M3 yang diberi $5 \mathrm{~kg}$ TKKS $+1.5 \mathrm{~kg}$ feses kerbau + $15 \mathrm{ml}$ EM-4 untuk unsur C-Organik.
Tabel 1. Hasil analisis kandungan hara pupuk organik tandan kosong kelapa sawit

\begin{tabular}{ccccc}
\hline $\begin{array}{c}\text { Dosis } \\
(\mathbf{m l})\end{array}$ & $\begin{array}{c}\text { N-Total } \\
\mathbf{( \% )}\end{array}$ & $\begin{array}{c}\text { P-Total } \\
(\mathbf{\%})\end{array}$ & $\begin{array}{c}\text { K-Total } \\
\mathbf{( \% )}\end{array}$ & $\begin{array}{c}\text { C-Total } \\
\mathbf{( \% )}\end{array}$ \\
\hline 0 & 2.03 & 0.33 & 2.35 & 37.00 \\
5 & 2.23 & 0.40 & 3.01 & 36.23 \\
10 & 1.92 & 0.31 & 5.02 & 38.57 \\
15 & 1.91 & 0.31 & 3.96 & 39.10 \\
20 & 1.95 & 0.34 & 3.66 & 38.63 \\
25 & 2.15 & 0.30 & 3.76 & 38.63 \\
SNI & 0.40 & 0.10 & 0.20 & $27-58$ \\
\hline
\end{tabular}

Hasil penelitian sangat berbeda dari literatur ataupun penelitian yang lain, dimana pada penelitian ini persentase kadar hara seperti N-total (kisaran 1.91\% -2.23\%), P-total (kisaran $0.30 \%-0.40 \%$ ), dan K (kisaran 2.35\% - 5.02\%) lebih rendah daripada penelitian lain yang dilakukan Toiby et al., (2015) pada tandan kosong kelapa sawit dengan EM-4 pada dosis yang berbeda hasil rata-rata $\mathrm{N}, \mathrm{P}$, K secara berturut-turut 6.79\%, 3.04\%, 8.08\%, dan lebih tinggi dari penelitian Yunindanova (2009) pada tandan kosong kelapa sawit tanpa EM-4 dengan hasil rata-rata $N, P, K$ secara berturut-turut $1.20 \%, 0.06 \%$ dan $1.19 \%$. Begitu pula dengan kadar C-Organik tinggi (kisaran $36.23 \%-39.10 \%)$ lebih rendah dibandingkan dengan penelitian Toiby et al., (2015) kisaran $6.30 \%-51.7 \%$.

Tingginya unsur hara yang terkandung dalam pupuk organik tandan kosong kelapa sawit ini diduga karena adanya beberapa faktor antara lain seperti, EM-4 dan feses kerbau. Dwiyantono et al., (2014) menjelaskan bahwa dalam keadaan segar, feses kerbau memiliki kandungan air sekitar 81\%, kandungan $\mathrm{N}$ sebesar $0,25 \%$, rasio $\mathrm{C} / \mathrm{N} 25-28$, berbeda dengan feses ternak sapi potong yang memiliki kandungan air 80\%, kandungan $\mathrm{N}$ sebesar $0,3 \%$, dan rasio C/N 20\%-25\%. Dari hasil penelitian di atas terlihat pada perlakuan M2 dan M3 memiliki nilai kadar hara P-total tidak mengalami perubahan. Kadar $\mathrm{K}$ tertinggi terdapat pada perlakuan M2 yaitu $5.02 \%$. Berdasarkan Standar Nasional Indonesia spesifikasi SNI: 19-7030-2004 hasil kadar hara unsur makro pada penelitian ini sudah memenuhi standar mutu pupuk organik seperti bahan organik $27 \%$ - 58\%, Nitrogen $0.40 \%$, Fosfor $\left(\mathrm{P}_{2} \mathrm{O}_{5}\right)$ 0.10\% dan Kalium 0.20\%.

\section{Kandungan Nitrogen}

Kandungan $\mathrm{N}$ tertinggi terdapat pada M1 yaitu $2.23 \%$, dan kadar hara $\mathrm{N}$ yang paling rendah terdapat pada sampel M3 yaitu 1.91\%. Persentase $\mathrm{N}$ pada pupuk organik ini cukup rendah dari penelitian Toiby et al., (2015) yang rata-rata berkisar $6 \%$ dan cukup tinggi dari penelitian Yunindanova (2009) yang rata-rata 
hanya berkisar 1\%. Menurut Ayunin et al., (2016) peningkatan kadar $\mathrm{N}$ dapat terjadi karena padatan tervolatil atau bahan organik yang terdegradasi lebih besar dibandingkan NH3 yang tervolatilisasi.

Dari Tabel 2. dapat dilihat hasil dari analisis regresi linier sederhana untuk kandungan $\mathrm{N}$ didapatkan persamaan regresinya $Y=2.050-0.001 X$, angka konstan dari unstandardized coefficients yang dalam penelitian ini sebesar 2.050. Angka ini berupa angka konstan yang mempunyai arti bahwa jika tidak ada penambahan dosis EM-4 maka nilai $\mathrm{N}$ sebesar 2.050. Angka koefisien regresi sebesar -0.001 mempunyai arti bahwa setiap penambahan $1 \mathrm{ml}$ EM-4 maka nilai $\mathrm{N}$ akan menurun sebesar 0.001. Angka r2 sebesar 0.01 atau sama dengan $1 \%$, angka tersebut berarti bahwa sebesar $1 \%$ nilai $\mathrm{N}$ dapat dijelaskan dengan nilai pengaruh dosis EM-4.

Sedangkan sisanya yaitu 99\% dijelaskan oleh faktor lain seperti adanya TKKS karena komponen terbesar dari TKKS adalah selulosa $40 \%$ - 60\%, disamping komponen lain yang jumlahnya lebih kecil seperti hemiselulosa 20\% - 30\%, dan lignin $15 \% \quad-30 \%$ (http://www.petanihebat.com). Berdasarkan hasil nilai pupuk organik TKKS tersebut rata-rata sudah memenuhi kandungan $\mathrm{N}$ menurut SNI: $19-7030-2004$ yaitu $\geq 0.40 \%$ dengan tidak ada kandungan $\mathrm{N}$ yang rendah menurut SNI pada setiap perlakuan dan sampel.

Nitrogen (N) merupakan unsur esensial bagi tumbuhan, $\mathrm{N}$ dibutuhkan dalam jumlah yang banyak, $\mathrm{N}$ di dalam tanah dan tanaman bersifat sangat mobile, sehingga keberadaan $\mathrm{N}$ di dalam tanah cepat berubah atau bahkan hilang. Kehilangan $\mathrm{N}$ dapat melalui denitrifikasi, volatilisasi, pengangkutan hasil panen atau pencucian dan erosi permukaan tanah. Hilangnya $\mathrm{N}$ melalui pencucian umum terjadi pada tanah-tanah yang bertekstur kasar, kandungan bahan organik sedikit dan nilai kapasitas tukar kation (KTK) rendah. Rendahnya kandungan unsur $\mathrm{N}$ serta unsur hara lain dapat terjadi pada tanah yang memiliki tingkat kemasaman tinggi $(\mathrm{pH}$ 5.5), hal ini umum terjadi pada tanah yang diusahakan dalam bidang pertanian, seperti pada tanah Entisol, Inceptisol dan Ultisol (Nariratih et al., 2013).

\section{Kandungan Fosfor}

Hasil pengujian unsur kadar $\mathrm{P}$ pada penelitian ini menunjukkan kandungan yang paling tinggi terdapat pada sampel M1 yaitu $0.40 \%$ dan kadar unsur $P$ terendah terdapat pada sampel M5 yaitu sebesar $0.30 \%$. Nilai hasil kadar unsur $\mathrm{P}$ ini sudah memenuhi standar kandungan Fosfor menurut SNI: 19$7030-2004 \quad$ yaitu $\geq 0.10 \%$.

Tabel 2. Hasil Analisis Regresi Linier Kandungan Hara

\begin{tabular}{ccccc}
\hline Variabel Dependen & Pers. Regresi Linier & $\mathbf{r}^{\mathbf{2}}$ & $\mathbf{S i g} \mathbf{<} \mathbf{0 . 0 5}$ & Kesimpulan \\
\hline Nitrogen & $\mathrm{Y}=2.05-0.001 \mathrm{X}$ & 0.01 & $0.424>0.05$ & Tidak Signifikan \\
Fospor & $\mathrm{Y}=0.355-0.002 \mathrm{X}$ & 0.233 & $0.166>0.05$ & Tidak Signifikan \\
Kalium & $\mathrm{Y}=3.06+0.045 \mathrm{X}$ & 0.221 & $0.174>0.05$ & Tidak Signifikan \\
C-Organik & $\mathrm{Y}=36.89+0.09 \mathrm{X}$ & 0.558 & $0.044<0.05$ & Signifikan \\
\hline
\end{tabular}

Dari Tabel 2. dapat dilihat hasil dari analisis regresi linier sederhana untuk kandungan $\mathrm{P}$ didapatkan persamaan regresinya $Y=0.355-0.002 X$, angka konstan dari unstandardized coefficients yang dalam penelitian ini sebesar 0.355. Angka ini berupa angka konstan yang mempunyai arti bahwa jika tidak ada penambahan dosis EM-4 maka nilai $P$ sebesar 0.355 . Angka koefisien regresi sebesar -0.002 mempunyai arti bahwa setiap penambahan $1 \mathrm{ml}$ EM-4 maka nilai $P$ akan menurun sebesar 0.002. Angka r2 sebesar 0.233 atau sama dengan 23.3\%, angka tersebut berarti bahwa sebesar $23.3 \%$ nilai $P$ dapat dijelaskan dengan pengaruh dosis EM4, sedangkan sisanya yaitu $76.7 \%$ dijelaskan oleh faktor lain seperti TKKS, dan feses kerbau. Hubungan antara $P$ dan dosis EM-4 yang dilihat dari angka signifikansi sebesar 0.166 yang lebih besar dari 0.05 artinya tidak ada hubungan yang signifikan antara nilai $P$ dan dosis EM-4.

Aziz (2013) mengungkapkan bahwa $P$ adalah zat yang dapat berpendar karena mengalami fosforesens, unsur kimia yang atom 15. $\mathrm{P}$ berupa nonlogam bervalensi banyak, termasuk golongan $\mathrm{N}$, banyak ditemui dalam batuan fosfat anorganik dan dalam semua sel hidup tetapi tidak pernah ditemui dalam bentuk unsur bebasnya. $P$ dapat berada dalam empat bentuk atau lebih alotrop, yaitu putih/ kuning, merah, dan hitam/ ungu. Fosfor $(P)$ termasuk unsur hara makro esensial yang sangat penting untuk pertumbuhan tanaman, tetapi kandungannya di dalam tanah lebih rendah dibanding Nitrogen $(\mathrm{N})$, Kalium $(\mathrm{K})$, dan Kalsium (Ca).

Kandungan Kalium

Kandungan unsur $\mathrm{K}$ yang paling tinggi terdapat pada sampel M2 yaitu $5.02 \%$ dan 
kadar $\mathrm{K}$ yang terendah terdapat pada sampel M0 yaitu 2.35\%. Menurut Gunawan et al., (2015) peningkatan kadar $\mathrm{K}$ dalam kompos dikarenakan proses pendekomposisian berjalan dengan baik dimana peningkatan $\mathrm{K}$ disebabkan oleh bakteri pelarut $\mathrm{K}$ dalam kompos seperti Bacillus mucilaginous dan ketersediaan mikroorganisme akan sangat mempengaruhi kadar $\mathrm{K}$ kompos.

Tabel 3. Hasil Rasio C/N

\begin{tabular}{cccc}
\hline $\begin{array}{c}\text { Dosis } \\
(\mathbf{m l})\end{array}$ & $\begin{array}{c}\text { N-Total } \\
(\%)\end{array}$ & $\begin{array}{c}\text { C-Total } \\
(\%)\end{array}$ & $\begin{array}{c}\text { C/N Rasio } \\
(\%)\end{array}$ \\
\hline 0 & 2.03 & 37.00 & 18.17 \\
5 & 2.23 & 36.23 & 16.23 \\
10 & 1.92 & 38.57 & 20.23 \\
15 & 1.91 & 39.10 & 20.73 \\
20 & 1.95 & 38.63 & 19.87 \\
25 & 2.15 & 38.63 & 18.00 \\
SNI & 0.40 & $27-58$ & $10-20$ \\
\hline
\end{tabular}

Dari Tabel 2. dapat dilihat hasil dari analisis regresi linier sederhana untuk kandungan $\mathrm{K}$ didapatkan persamaan regresi $Y=3.06+0.045 X$, angka konstan dari unstandardized coefficients yang dalam penelitian ini sebesar 3.06. Angka ini berupa angka konstan yang mempunyai arti bahwa jika tidak ada penambahan dosis EM-4 maka nilai $\mathrm{K}$ sebesar 3.06. Angka koefisien regresi sebesar 0.045 mempunyai arti bahwa setiap penambahan $1 \mathrm{ml}$ EM-4 maka nilai $\mathrm{K}$ akan naik sebesar 0.045. Angka r2 sebesar 0.221 atau sama dengan 22.1\%, angka tersebut berarti bahwa sebesar $22.2 \%$ nilai $\mathrm{K}$ dapat dijelaskan dengan pengaruh dosis EM-4, sedangkan sisanya yaitu $77.8 \%$ dijelaskan oleh faktor lain seperti TKKS dan feses kerbau.

Wati et al., (2014) mengatakan bahwa kotoran ternak mengandung $\mathrm{N}, \mathrm{P}$ dan $\mathrm{K}$ serta kandungan selulosa yang tinggi dan mudah diuraikan oleh bakteri, selain itu kotoran ini mudah didapatkan dan menjadi limbah yang tidak termanfaatkan. Oleh karena itu, faktor yang mempengaruhi keselarasan model regresi $\mathrm{N}, \mathrm{P}$, dan $\mathrm{K}$ adalah feses kerbau. Hubungan antara $\mathrm{K}$ dan dosis EM-4 yang dilihat dari angka signifikansi sebesar 0.174 yang lebih besar dari 0.05 artinya tidak ada hubungan yang signifikan antara nilai $\mathrm{K}$ dan dosis EM-4.

Kadar $\mathrm{K}$ pada penelitian ini cukup meningkat, peningkatan unsur kadar $\mathrm{K}$ ini diduga karena adanya proses dekomposisi bahan organik yang menghasilkan asam-asam organik dan unsur hara seperti asam fulvat dan asam humat. Menurut Kastono (2005) adanya asam humat dan asam fulvat dalam tanah mempercepat pelepasan kembali ion $\mathrm{K}+$ yang terikat diantara kisi-kisi mineral. Nilai hasil kadar unsur $\mathrm{K}$ ini telah memenuhi standar kandungan K menurut SNI: 19-7030-2004 yaitu $0.20 \%$ untuk batas minimum dan tidak ada batasan untuk nilai maksimum.

\section{Rasio C/N}

Rasio $\mathrm{C} / \mathrm{N}$ pada penelitian ini diukur dengan membandingkan kandungan COrganik dengan kandungan N-total. Kadar COrganik pada penelitian ini cukup tinggi. Kadar C-Organik tertinggi terdapat pada sampel M3 yaitu $39.10 \%$ dengan dasar dosis EM-4 15ml dan kadar C-Organik terendah terdapat pada sampel M1 dengan dosis EM-4 $5 \mathrm{ml}$ yaitu $36.23 \%$.

Dari Tabel 2. dapat dilihat hasil dari analisis regresi linier sederhana untuk kandungan C-Organik didapatkan persamaan regresinya $Y=36.892+0.091 X$, angka konstan dari unstandardized coefficients yang dalam penelitian ini sebesar 36.892. Angka ini berupa angka konstan yang mempunyai arti bahwa jika tidak ada penambahan dosis EM-4 maka nilai C-Organik sebesar 36.892. Angka koefisien regresi sebesar 0.091 mempunyai arti bahwa setiap penambahan $1 \mathrm{ml}$ EM-4 maka nilai C-Organik akan naik sebesar 0.091 . Angka r2 sebesar 0.558 atau sama dengan $55.8 \%$, angka tersebut berarti bahwa sebesar $55.8 \%$ nilai C-Organik dapat dijelaskan dengan pengaruh dosis EM-4, sedangkan sisanya yaitu $44.2 \%$ harus dijelaskan oleh faktor lain seperti bahan organik TKKS, feses kerbau dan EM-4.

Palupi (2015) mengatakan kandungan C-Organik dalam kompos menunjukkan banyaknya bahan organik yang terdapat dalam kompos selama proses pelapukan berlangsung. Semakin intensif pelapukan bahan organik berlangsung, maka akan semakin sedikit keberadaan karbon organik dalam suatu bahan. Hubungan antara COrganik dan dosis (Tabel 2.) EM-4 yang dilihat dari angka signifikansi sebesar 0.044 yang lebih kecil dari 0.05 artinya ada hubungan yang signifikan antara nilai C-Organik dan dosis EM-4.

Hasil perhitungan rasio $\mathrm{C} / \mathrm{N}$ pada penelitian ini yang telah dijabarkan pada Tabel 2. telah memenuhi batas minimum dan maksimum dalam ukuran SNI : 19-7030-2004, namun terdapat 2 sampel yang melebihi batas maksimum rasio C/N pada SNI : 19-7030-2004 yaitu sampel M2 dan M3. Co-composting merupakan pengomposan limbah padat menggunakan lebih dari satu bahan dengan menggabungkan manfaat dari masing-masing bahan untuk mengoptimalkan hasil dari produk (kompos). Pencampuran bahan organik tersebut terutama didasarkan pada nilai rasio 
$\mathrm{C} / \mathrm{N}$ dan kandungan air. Adanya senyawa $\mathrm{N}$ anorganik pada campuran kompos menjadi salah satu faktor yang mempengaruhi proses pengomposan. Jika senyawa $\mathrm{N}$ rendah maka proses akan berjalan lama, sedangkan jika senyawa $\mathrm{N}$ berlebih maka akan terbentuk gas ammonia (Ismayana et al., 2014).

\section{Nilai Keasaman}

Pada Gambar 1. nilai pH yang didapatkan berkisar 7.30-9.35 yaitu bersifat basa, dengan kondisi keseluruhan yang terjadi selama pengomposan menghasilkan rata-rata 8.99 dan tidak memenuhi standar menurut SNI: 197030-2004 yaitu batas minimun 6.80 dan batas maksimum 7.49. Hasil nilai $\mathrm{pH}$ yang telah diukur hanya 1 sampel yang memenuhi standar menurut SNI: 19-7030-2004 yaitu sampel M5 (7.30) dengan hasil $\mathrm{pH}$ yang $>7$ bersifat basa, nilai ini terjadi pada minggu pertama dan minggu-minggu selanjutnya mengalami kenaikan yang melebihi batas maksimun dari standar SNI: 19-7030-2004, namun tetap dalam kondisi sifat basa.

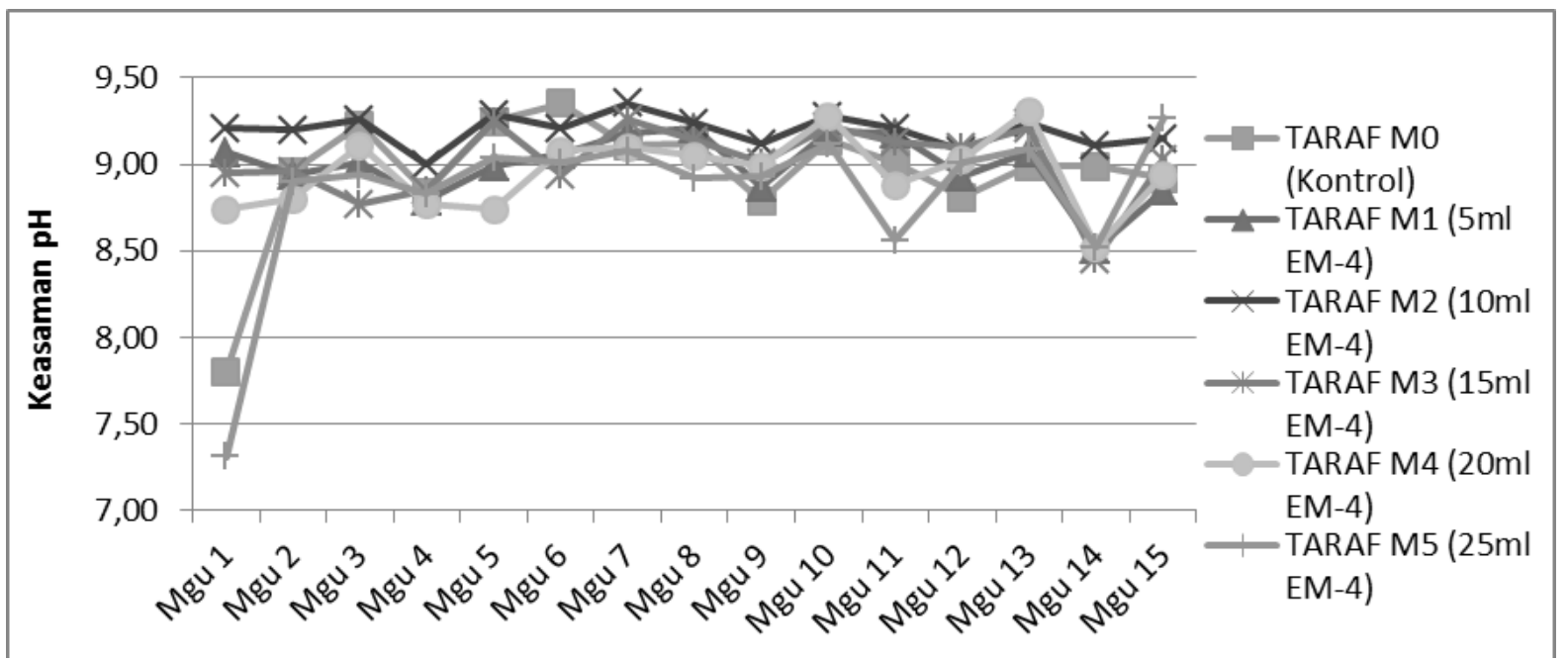

Gambar 1. Tingkat Keasaman pH Pupuk Organik

Kenaikan $\mathrm{pH}$ yang terjadi menurut Manuputty et al., (2012) diduga adanya reaksi dari kation-kation basa, terutama Kalium dan Natrium yang merupakan logam alkali pembentuk basa kuat; disamping Kalsium dan Magnesium yang dibebaskan selama proses dekomposisi. Kation-kation basa ini dapat menetralizir asam-asam organik yang dihasilkan selama dekomposisi bahan organik berlangsung. Meskipun kosentrasi asam-asam organik yang dibebaskan tinggi, tetapi asamasam organik merupakan asam lemah dengan derajat ionisasi yang kecil (alphanya mendekati nol), sehingga ion hidrogen yang dibebaskan oleh asam-asam organik tersebut tak mampu menigkatkan $\mathrm{pH}$ kompos. Reaksi yang alkalis dari kompos ini memungkinkan penggunaannya untuk menaikkan $\mathrm{pH}$ tanah mineral masam.

Analisis kadar keasaman $\mathrm{pH}$ pada pupuk organik ini dilakukan untuk melihat keberlangsungan proses fermentasi pengomposan untuk menguji mutu dari pupuk organik. Triyadi et al., (2015) mengungkapkan perubahan $\mathrm{pH}$ selama proses pengomposan diakibatkan oleh aktifitas mikroba, meningkatnya $\mathrm{pH}$ menjadi kondisi basa baik untuk proses pengomposan karena kondisi basa dapat menghambat pertumbuhan pathogen seperti jamur yang dapat hidup dalam kondisi asam.

Pada Tabel 3. menunjukkan hasil bahwa dosis EM-4 yang diberikan berpengaruh terhadap tingkat keasaman $(\mathrm{pH})$ pada pupuk organik yang mengalami fase naik turun. Hasil analisis perhitungan tingkat keasaman $(\mathrm{pH})$ pada pupuk organik menunjukkan hasil yang berbeda-beda, hasil analisis tidak berbeda nyata terjadi pada minggu $1,4,7,10$, dan minggu 15 . Hasil analisis berbeda nyata terjadi pada minggu 2 , $3,9,11$, dan minggu 13 . Hasil analisis sangat berbeda nyata terjadi pada minggu $5,6,8,12$, dan minggu 14.

\section{Aroma}

Pengamatan pengujian mutu pupuk organik untuk parameter aroma dilakukan secara organoleptik menggunakan panca indera hidung dan diujicobakan pada panelis tidak terlatih. Hasil pengamatan aroma dalam penelitian ini disajikan dalam bentuk nilai interpretasi skor. Uji responden aroma mayoritas mendapatkan interpretasi "Suka", namun ada beberapa butir pernyataan yang mendapatkan nilai "Agak Tidak Suka" dan "Sangat Suka". 
Tabel 3. Ringkasan Sidik Ragam pH.

\begin{tabular}{ccc}
\hline \multirow{2}{*}{ Peubah } & \multicolumn{2}{c}{ F Hitung } \\
\cline { 2 - 3 } Minggu 1 & 1.74 tn & KK \% \\
\hline Minggu 2 & 3.31 * & 1.40 \\
Minggu 3 & $3.22^{*}$ & 1.98 \\
Minggu 4 & 0.98 tn & 1.60 \\
Minggu 5 & $9.45^{\star *}$ & 1.31 \\
Minggu 6 & $5.65 * *$ & 1.18 \\
Minggu 7 & 0.60 tn & 2.64 \\
Minggu 8 & $4.19 * *$ & 1.08 \\
Minggu 9 & 2.04 * & 1.56 \\
Minggu 10 & 1.56 tn & 1.02 \\
Minggu 11 & $5.61 *$ & 2.00 \\
Minggu 12 & 7.46 ** & 0.76 \\
Minggu 13 & 9.07 * & 0.75 \\
Minggu 14 & 78.51 ** & 0.64 \\
Minggu 15 & 1.32 tn & 2.62 \\
\hline Keterangan : ** : Sangat Berbeda Nyata, * & Berbeda Nyata, tn : Tidak \\
Berbeda Nyata, KK : Koefisien \\
Keragaman.
\end{tabular}

Pada awal dari penelitian ini, bau yang dihasilkan oleh kompos pupuk organik beraroma kecut yang sangat menyengat hal ini disebabkan oleh larutan EM-4 dan feses kerbau. Aroma pupuk organik TKKS yang dihasilkan pada semua perlakuan ialah sama. Pada pengamatan minggu pertama aroma pupuk cukup menyengat. Hal ini terjadi karena adanya aktifitas fermentasi dari larutan EM-4. Pada pengamatan selanjutnya aroma menyengat pada pupuk organik semakin berkurang, dan pada pengamatan minggu kelima dan keenam aroma pupuk organik tidak menyengat atau beraroma seperti tanah, karena materi yang dikandungnya menyerupai tanah, hal ini menunjukkan bahwa pupuk telah matang. Dosis EM-4 yang diberikan menimbulkan aroma kecut pada setiap sampel, namun sedikit berbeda pada sampel kontrol yaitu sampel MO tanpa pemberian dosis EM-4. Pada sampel kontrol aroma yang ditimbulkan tidak terlalu kecut akan tetapi tetap menimbulkan aroma yang disebabkan oleh feses kerbau.

\section{Warna}

Warna kompos merupakan salah satu indikator fisik tingkat kematangan kompos. Pengamatan pengujian mutu pupuk organik untuk parameter warna dilakukan secara organoleptik menggunakan panca indera mata dan diujicobakan pada panelis tidak terlatih. Hasil pengamatan warna dalam penelitian ini disajikan dalam bentuk nilai interpretasi skor. Uji responden mendapatkan hasil responden yang mayoritas menjawab interpretasi "Sangat Suka" setiap mingggunya dengan beberapa minggu yang mendapatkan hasil interpretasi "Suka".

Keadaaan ini telah sesuai dengan kriteria yang dilihat pada SNI: 19-7030-2004. Secara umum Kusmiyarti (2013) mengatakan, proses pengomposan pupuk organik secara bertahap akan merubah warna material kompos kearah cokelat kehitaman akibat dari berlangsungnya transformasi bahan organik dan membentuk zat-zat humus, sebenarnya perubahan warna kompos tidak hanya disebabkan oleh perubahan yang bersifat sederhana seperti akibat perbedaan kelambaban material, tetapi juga disebabkan oleh berubahnya kandungan CO2 atau asamasam organik yang bersifat volatil.

\section{KESIMPULAN DAN SARAN}

\section{Kesimpulan}

Pemberian EM-4 pada pupuk organik TKKS menghasilkan mutu pupuk yang telah memenuhi SNI: 19-7030-2004. Pemberian EM-4 pada pupuk organik TKKS menghasilkan mutu pupuk yang telah memenuhi SNI: 197030-2004. Pemberian dosis EM-4 berturutturut : $5 \mathrm{ml}, 10 \mathrm{ml}$, dan $15 \mathrm{ml}$ membentuk sifat kimia terbaik untuk unsur $\mathrm{N}, \mathrm{P}, \mathrm{K}, \mathrm{C}$ dan sifat fisik yang telah memenuhi SNI: 19-7030-2004. Namun pada pengukuran $\mathrm{pH}$ pupuk organik TKKS tidak memenuhi SNI: 19-7030-2004.

\section{Saran}

Pentingnya dilakukan penelitian lanjutan terhadap penambahan dosis EM-4 dan bahan baku organik yang dapat menstabilkan nilai angka yang memenuhi SNI 19-7030-2004.

\section{DAFTAR PUSTAKA}

Anonim. 2017. www.hukumonline.com. Diakses pada 29 Februari 2017 (14:03). (http://www.petanihebat.com). Diakses pada 25 Oktober 2017 (07:04)

Ayunin, R.W., W.D. Nugraha, dan G. Samudro. 2016. Pengaruh Penambahan Pupuk Urea dalam Pengomposan Sampah Organik Secara Aerobik Menjadi Kompos Matang dan Stabil Diperkaya. Jurnal Teknik Lingkungan, 5(2):1-10.

Aziz, A. 2013. Analisis Kandungan Unsur Fosfor (P) dalam Kompos Organik Limbah Jamur dengan Aktivator Ampas Tahu. Jurnal Ilmiah Biologi "Bioscientist", 1(1):26-32.

Dwiyantono, R., Sutaryo, dan A. Purnomoadi. 2014. Perbandingan Kualitas 
Vermikompos yang Dihasilkan dari Feses Sapi dan Feses Kerbau. Animal Agriculture Journal 3(2):147-154.

Fatokah. 2012. Kandungan Fraksi Serat Rumput Raja (Pennisrctum purpureum $X$ Pennisetum thypoides) pada Pemotongan Pertama dengan Pemberian Pupuk Kandang Berbeda. Skripsi. Jurusan Agroteknologi Fakultas Pertanian dan Peternakan Universitas Islam Negeri Sultan Syarif Kasim Riau. Pekanbaru.

Gunawan, R., R. Kusmiadi, dan E. Prasetiyono. 2015. Studi Pemanfaatan Sampah Organik Sayuran Sawi (Brassica juncea L.) dan Limbah Rajungan (Portunus pelagicus) untuk Pembuatan Kompos Organik Cair. Jurnal Pertanian, 8(1):37-47.

Harahap, R.T., T. Sabrina., dan P. Marbun. 2015. Penggunaan Beberapa Sumber dan Dosis Aktivator Organik untuk Meningkatkan Laju Dekomposisi Kompos Tandan Kosong Kelapa Sawit. Jurnal Online Agroteknologi, 3(2):581589.

Ismayana, A., N.S. Indrasti., dan N. Erica. 2014. Pengaruh Rasio C/N Awal dan Laju Aerasi pada Proses CoComposting Blotong dan Abu Ketel. Jurnal Bumi Lestari, 14(1): $39-45$.

Jannah, W., D. Zul., dan B.L. Fibriarti. 2014. Aplikasi Mikroorganisme Lignoselulotik Indigenus Asal Tanah Gambut Riau dalam Pembuatan Kompos Tandan Kosong Kelapa Sawit (Elaies guinensis Jacq.). Jurnal Onlie Mahasiswa FMIPA, 1(2):543-553.

Kusmiyarti, T.B. 2013. Kualitas Kompos dari Berbagai Kombinasi Bahan Baku Limbah Organik. Agrotrop,3(1):83-92.

Manuputty, M.C., A. Jacob, dan J.P. Haumahu. 2012. Pengaruh Effective Inoculant Promi dan EM-4 Terhadap Laju Dekomposisi dan Kualitas Kompos dari Sampah Kota Ambon. Jurnal Agrologia, 1(2):143-151.

Marlina, E.T., Y.A. Hidayati., Tb. Betino A.K., dan W. Juanda. 2013. Analisis Kualitas Kompos dari Sludge Biogas Feses Kerbau. Jurnal IImu Ternak, 13(1):3134.

Nuryanto, E., B. Wirjosentono., T. Herawan., dan H. Agusnar. 2013. Ekstraksi dan Karakterisasi Selulosa dari Tandan Kosong Kelapa Sawit serta Pemanfaatannya untuk Produksi Selulosa Asetat. J.pen. Kelapa Sawit, 21(1):40-48.
Palupi, N.P. 2015. Karakter Kimia Kompos dengan Dekomposer Mikroorganisme Lokal Asal Limbah Sayuran. Jurnal Ziraa'ah, 40(1):54-60.

Puspa, E. 2014. Pertumbuhan Pegagan (Contella asiatica L.Urban) pada Media Tumbuh yang Berbeda dengan Pemberian Dua Jenis Pupuk Organik. Skripsi. Jurusan Agroteknologi Fakultas Pertanian dan Peternakan UIN Suska Riau. Pekanbaru.

Rivani, M., T. Herawan., Nasrullah, dan H. Buntaran. 2013. Kinetika Reaksi Hidrolisis Selulosa Tandan Kosong Kelapa Sawit Menggunakan Sulfat Encer. J. pen. Kelapa Sawit, 21(3):155123.

Sahwan, F.L., S. Wahyono., dan F. Suryanto. 2011. Kualitas Kompos Sampah Rumah Tangga yang Dibuat dengan Menggunakan "Komposter" Aerobik. Jurnal Teknik Lingkungan, 12(3):233240.

Suherman, I., A. Awaluddin., dan Itnawita. 2014. Analisis Kualitas Kompos dari Campuran Tandan Kosong Kelapa Sawit dengan Kotoran Ayam Menggunakan Limbah Cair Pabrik Kelapa Sawit dan EM-4. JOM FMIPA, 1(2):195-204.

Surilawati. 2013. Pertumbuhan dan Hasil Dua Varietas Kacang Hijau (Vigma radiata) dengan Pemberian Kompos Tandan Kelapa Sawit di Lahan Gambut. Skripsi. Jurusan Agroteknologi Fakultas Pertanian dan Peternakan Universitas Islam Negeri Sultan Sarif Kasim Riau. Pekanbaru.

Tiryadi, C., Y. Rahman, B. Trisakti. 2015. Pengaruh Tinggi Tumpukan pada Pengomposan Tandan Kosong Kelapa Sawit Menggunakan Pupuk Organik Aktif dari Limbah Cair Pabrik Kelapa Sawit di dalam Komposter Menara Drum. Jurnal Teknik Kimia USU, 4(4):25-31.

Toiby, A.R., E. Rahmadani, dan Oksana. 2015. Perubahan Sifat Kimia Tandan Kosong Kelapa Sawit yang di Fermentasi dengan EM-4 pada Dosis dan Lama Pemeraman yang Berbeda. Jurnal Agroteknologi, 6(1):1-8.

Wahyono, S., F.L. Sahwandan, dan F. Suryanto. 2008. Tinjauan Terhadap Perkembangan Penelitian Pengolahan Limbah Padat Pabrik Kelapa Sawit. Jurnal Teknik Lingkungan Edisi Khusus, : 67-74.

Wati, L., Y. Ahda, dan D. Handayani. 2014. Pengaruh Volume Cairan Rumen Sapi 
Terhadap Bermacam Feses dalam Menghasilkan Biogas. Eksakta, 1:20-28.

Yuliarti, N. 2009. 1001 Cara Menghasilkan Pupuk Organik. Cetakan 1. Lily Publisher. Yogyakarta. 70 hal.

Yunindanova, M. B. 2009. Tingkat Kematangan Kompos Tandan Kosong Kelapa Sawit dan Penggunaan Berbagai Jenis Mulsa Terhadap Pertumbuhan dan Produksi Tanaman Tomat (Lycopersicon esculentum Mill.) dan Cabai (Capsicum annuum L.). Skripsi. Jurusan Agronomi Fakultas Pertanian Institut Pertanian Bogor. Bogor.

Yuniwati, M., F. Iskarima., dan A. Padulemba. 2012. Optimasi Kondisi Proses Pembuatan Kompos dari Sampah Organik dengan Cara Fermentasi Menggunakan EM-4. Jurnal Teknologi, 5(2): 172-181. 